\title{
Feeding interactions in an assemblage of terrestrial carnivores in central Mexico
}

\author{
Yuriana Gómez-Ortiz ${ }^{1}$ Octavio Monroy-Vilchis ${ }^{1 *}$ and Germán D Mendoza-Martínez²
}

\begin{abstract}
Background: We evaluated the strategies of resources partitioning among species, dietary overlap and niche breadth in an assemblage of carnivores integrated by top predators (Puma concolor and Panthera onca) and mesopredators (Leopardus pardalis, Leopardus wiedii, Puma yagouaroundi, Nasua narica and Urocyon cinereoargenteus). The aim of this study was to investigate the mechanisms explaining the coexistence among species at a temperate zone in central Mexico.

Results: We collected 259 scats of carnivores and identified 45 food items. The analysis showed the common consumption of mammals in the assemblage, and the correspondence analysis showed three guilds: 1) top predators associated with the use of medium-sized mammals and the exclusive consumption of large mammals, 2) carnivore mesopredators associated with the consumption of small mammals and birds and 3) omnivore mesopredators associated with the consumption of arthropods and plants. The dietary overlap analysis indicated a low overlap between guilds and a high overlap within them. Top predators were specialist foragers, whilst the carnivore mesopredators showed generalist consumption.

Conclusions: The coexistence in this carnivore assemblage seems to be related to body size, morphology and prey segregation because such characteristics suggest the presence of three guilds. We observed high dietary overlap within guilds and resource partitioning between guilds.
\end{abstract}

Keywords: Coexistence; Community; Niche breadth; Niche overlap; Trophic interactions

\section{Background}

The evaluation of feeding relationships between predators, prey and their environment is used to identify factors structuring communities (Carvalho and Gomes 2004). To reach this aim, it is necessary to analyse trophic interactions between species that use similar resources, namely guilds (Root 1967; Jaksic 1981). The guild approach allows to explain the association among species, the ecological structure and community dynamics (Carvalho and Gomes 2004; Zapata et al. 2007). Ecological interactions and the mechanisms involved in resource partitioning and species coexistence are studied in relation to food, space or time segregation (MacArthur and Levins 1967; Schoener 1974). The knowledge of trophic structure in carnivore communities improves their management and conservation,

\footnotetext{
* Correspondence: tavomonroyvilchis@gmail.com

'Estación Biológica Sierra Nanchititla, Facultad de Ciencias, Universidad Autónoma del Estado de México, Instituto Literario 100, Colonia Centro, Toluca, CP 50000, México

Full list of author information is available at the end of the article
}

particularly in scarcely studied communities such as temperate zones (Ray and Sunquist 2001; Guerrero et al. 2002; Carvalho and Gomes 2004).

The predation theory predicts a convergence of trophic niches when resources are abundant (Schoener 1982), such that the dietary overlap might suggest high abundance of resources in the environment and moderate competition (Silva-Pereira et al. 2011). Because carnivore communities are structured by intraguild predation and competition, all members play important ecological roles in the ecosystem and show different strategies to coexist (Bianchi et al. 2011). Likewise, the presence of generalist predators in the ecosystem induces the exploitation of a wide range of prey by other carnivores (Pianka 1973). Thus, the opportunistic ability of some species represents an advantage in the use of resources and favours coexistence on the guild (Jaksic et al. 1996; Guerrero et al. 2002).

We considered that the body size of predators influences the community structure and resource sharing between species (Simberloff and Dayan 1991; Hayward

\section{曾 Springer}


et al. 2006). We defined the top predators as species occupying the apex trophic position in a community (largebodied) and mesopredators as species occupying trophic positions below them (medium-bodied, Ritchie and Johnson 2009). We investigated the feeding strategies that may explain the coexistence among members of a carnivore assemblage at a temperate zone of central Mexico in relation to morphological similarity. As the body size of predators is thought to shape community structure, we expected high dietary overlap between Puma concolor and Panthera onca (top predators), between Leopardus pardalis, Leopardus wiedii and Puma yagouaroundi (carnivore mesopredators) and between Nasua narica and Urocyon cinereoargenteus (omnivore mesopredators).

We obtained data regarding diet composition, niche overlap and niche breadth to identify resource partitioning strategies. The study was conducted through the analysis of field-collected scats. The most effective identification of scats has been performed using molecular techniques such as bile acids identification using thin-layer chromatography (TLC) or DNA extraction (Ernest et al. 2000; Cazón and Sühring 1999). TLC has been suggested as an effective means of identification of carnivore scats, since the profiles of faecal bile acids have been shown to be speciesspecific. Species often display a unique bile acid profile, so TLC uses specific differences in bile acid profiles to distinguish between species (Major et al. 1980; Fernández et al. 1997; Taber et al. 1997; Ray and Sunquist 2001). This is an inexpensive and non-invasive technique that has been effective with carnivore species, although some studies have described a number of limitations when applied in omnivores due to the presence of vegetal pigments (Cazón and Sühring 1999). Our study is the first to describe the diet of small felids (L. pardalis, $L$. wiedii and $P$. yagouaroundi) using TLC, which improves species assignment and allows us to analyse the association strategies among guilds.

\section{Methods}

\section{Study area}

Sierra Nanchititla Natural Park (SNNP) is located in central Mexico, between extreme coordinates $100^{\circ} 36^{\prime} 49^{\prime \prime}$ $100^{\circ} 16^{\prime} 03^{\prime \prime}$ west longitude and $18^{\circ} 45^{\prime} 13^{\prime \prime}-19^{\circ} 04^{\prime} 22^{\prime \prime}$ north latitude. Altitude ranges from 410 to 2,080 m a.s.l. and covers $663.87 \mathrm{~km}^{2}$ (Figure 1). The vegetation types are oak forest (30\%), induced grasslands (30\%), deciduous tropical forest (18\%), pine-oak forest (17\%) and cultivations (4\%, Monroy-Vilchis et al. 2008). Overall, 53 species of mammals have been recorded, belonging to 6 orders, including 17 families and 38 genera; of these, 14 species are carnivores, 11 are endemic and 9 are endangered or considered rare (Monroy-Vilchis et al. 2011).

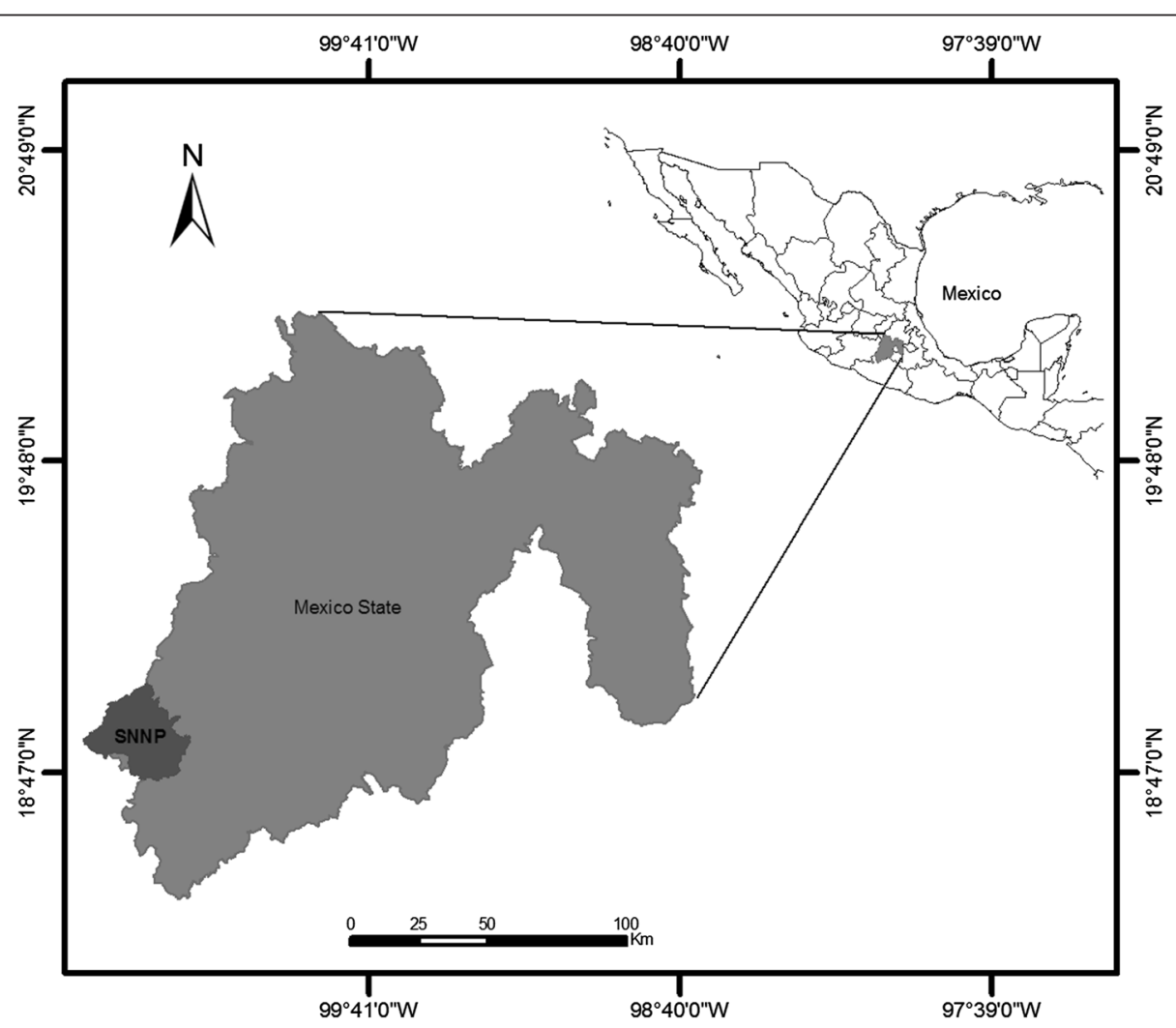

Figure 1 Geographic position of Sierra Nanchititla Natural Park (SNNP) in central Mexico. 


\section{Scat identification}

From September 2009 to March 2012, carnivore scats were collected over different paths distributed throughout the SNNP. The scats were identified considering the diameter, associated traces (tracks or scrapes) and extraction of bile acid using TLC (Salame-Méndez et al. 2012). We collected two known-origin reference scats from individual $P$. concolor (three individuals) and $P$. onca (three individuals) and one known-origin reference scat from individual L. pardalis (six individuals), L. wiedii (eight individuals) and P. yagouaroundi (six individuals). The reference bile acid profiles were obtained through the following methods. We used a gram approximately of each scat collected and preserved it in ethanol; the solution was mixed and $1 \mu \mathrm{l}$ of the supernatants was used to extract bile acids. We used two chromatography techniques to separate all bile acids by polarity, each one with a different mobile phase: 1 ) chloroform:methanol:acetic acid (80:12:0.5 $v / v)$ and 2) chloroform:ethanol:acetic acid (80:45:3 $v / v)$.

Samples were run against a known mixture of eight bile acids (cholic acid, chenodeoxycholic acid, deoxycholic acid, lithocholic acid, taurodeoxycholic acid, taurocholic acid, glycolic acid and dehydrocholic acid) and cholesterol, from Sigma-Aldrich ${ }^{\circ}$ (St. Louis, MO, USA). The bile acid spots of the mixtures were identified and RF values were calculated as the ratio of the distance moved by the solute (i.e. bile acid) and the distance moved by the solvent front along the TLC plate. Finally, each bile acid profile obtained from fieldcollected scats was compared against reference bile acid profiles extracted from known-origin reference scats.

\section{Diet composition}

The scat analysis was based on the standard methodology reported by Monroy-Vilchis et al. (2009a) and Gómez-Ortiz et al. (2011). Food items were identified considering remains in scats (hair, bones, claws, teeth, seeds, feathers etc.). Mammalian identifications were carried out through hair identification (Monroy-Vilchis and Rubio-Rodríguez 2003). Birds, reptiles, arthropods and fruits were identified by comparing them with specimen collections.

The contribution of each food item was presented as follows: the frequency of occurrence (FO), defined as the percentage of presences of a given food item in the total number of scats, and the percentage of occurrence (PO), obtained as the number of occurrences of a given food item divided by the total food items identified.

The resource partitioning among species was evaluated using an ordination procedure that permits the arrangement of similar species (Ray and Sunquist 2001). We applied a correspondence analysis using the frequency of occurrence of each food item. A matrix was constructed by grouping food items; mammals (commonly consumed in the assemblage) were separated into three groups according to body size: large mammals $(>6.13 \mathrm{~kg}$, maximum biomass ingested by puma/day, Monroy-Vilchis et al. 2013), medium-sized mammals ( $>1$ and $<6.13 \mathrm{~kg}$ ) and small mammals $(<1 \mathrm{~kg})$, birds, reptiles, arthropods and plants.

The estimates of niche were calculated through frequency of occurrence; niche breadth was calculated using Levins' index $\left(B^{\prime}\right)$, which ranges from 0 (specialist foraging) to 1 (generalist foraging). Dietary overlap was measured using Pianka's index; this ranges from 0 (total separation) to 1 (total overlap). Pairwise niche overlap values were calculated in the software EcoSim 7.0 (Gotelli and Entsminger 2005). We compared the observed overlap in the diet of this assemblage with null models of dietary overlap generated using the niche overlap module in this software. To determine this probability, 10,000 interactions were randomly generated with a level of significance of 0.05 . The RA3 algorithm was used because it preserves the specialisation of each species, but allows for the potential use of other resources (Winemiller and Pianka 1990). We assumed that all food items were equally available to all species, due to the lack of data regarding their availability.

\section{Results}

In total, 263 carnivore scats were identified. The largest number of scats was from $U$. cinereoargenteus (90), whilst the rest were from $P$. concolor (54), P. yagouaroundi (42), L. pardalis (21), N. narica (20), L. wiedii (16) and $P$. onca (16). All scats, excluding four belonging to Canis latrans (1) and Procyon lotor (3), were used in the dietary analysis.

We found 45 food items in a total of 259 carnivore scats examined. We identified $51.10 \%$ of food items belonging to mammals, $24.40 \%$ to plants, $12 \%$ to arthropods, $8.10 \%$ to birds and $4.40 \%$ to reptiles. One mammal, one bird and two plants were not identified.

\section{Trophic structure of carnivore assemblage}

It was found that all members of this carnivore assemblage consumed mammals, with differences in the body size and species consumed, although these were more frequent in diet of felids ( $>50 \%)$. Particularly, felids showed a key association with Dasypus novemcinctus. Overall, reptiles and birds were rarely consumed, and the occasional consumption of lagomorphs was evident in this assemblage.

The correspondence analysis generated two axes that explain approximately $90 \%$ of the total variation in diet. Axis I (68.27\% of variance) showed a clear separation of top predators ( $P$. onca and $P$. concolor), characterised by the consumption of large- and medium-sized mammals. Axis II (19.81\%) clearly separates mesopredators into 
Table 1 Diet of carnivore assemblage analysed through percentage of occurrence and frequency of occurrence, central Mexico

\begin{tabular}{|c|c|c|c|c|c|c|c|c|c|c|c|c|c|c|}
\hline \multirow[t]{3}{*}{ Species } & \multirow{2}{*}{\multicolumn{2}{|c|}{$\begin{array}{l}\begin{array}{l}\text { Puma } \\
\text { concolor }\end{array} \\
(n=54)\end{array}$}} & \multirow{2}{*}{\multicolumn{2}{|c|}{$\begin{array}{l}\text { Panthera } \\
\text { onca } \\
(n=16) \\
\end{array}$}} & \multirow{2}{*}{\multicolumn{2}{|c|}{$\begin{array}{l}\text { Leopardus } \\
\text { wiedii } \\
(n=16)\end{array}$}} & \multirow{2}{*}{\multicolumn{2}{|c|}{$\begin{array}{l}\text { Leopardus } \\
\text { pardalis } \\
(n=21)\end{array}$}} & \multirow{2}{*}{\multicolumn{2}{|c|}{$\begin{array}{l}\begin{array}{l}\text { Puma } \\
\text { yagouaroundi }\end{array} \\
(n=42)\end{array}$}} & \multirow{2}{*}{\multicolumn{2}{|c|}{$\begin{array}{l}\text { Nasua } \\
\text { narica }\end{array}$}} & \multirow{2}{*}{\multicolumn{2}{|c|}{$\begin{array}{l}\begin{array}{l}\text { Urocyon } \\
\text { cinereoargenteus }\end{array} \\
(n=90)\end{array}$}} \\
\hline & & & & & & & & & & & & & & \\
\hline & $\mathrm{PO}$ & FO & $\mathrm{PO}$ & FO & $\mathrm{PO}$ & FO & $\mathrm{PO}$ & FO & $\mathrm{PO}$ & FO & $\mathrm{PO}$ & FO & $\mathrm{PO}$ & FO \\
\hline \multicolumn{15}{|l|}{ Mammals } \\
\hline Baiomys musculus & - & - & - & - & - & - & 7.41 & 9.52 & - & - & - & - & - & - \\
\hline Bassariscus astutus & - & - & - & - & 6.67 & 6.25 & - & - & 1.78 & 2.38 & - & - & - & - \\
\hline Capra hircus & 3.33 & 3.7 & 13.04 & 18.75 & - & - & - & - & - & - & - & - & - & - \\
\hline Conepatus leuconotus & - & - & 4.35 & 6.25 & - & - & - & - & - & - & - & - & - & - \\
\hline Dasypus novemcinctus & 38.33 & 42.59 & 39.13 & 56.25 & 6.67 & 6.25 & 7.41 & 9.52 & 5.36 & 7.14 & - & - & - & - \\
\hline Didelphis virginiana & 1.67 & 1.85 & - & - & 6.67 & 6.25 & 3.7 & 4.76 & - & - & - & - & - & - \\
\hline Geomyidae & - & - & - & - & - & - & - & - & 1.79 & 2.38 & - & - & - & - \\
\hline Liomys irroratus & 1.67 & 1.85 & - & - & 33.33 & 31.25 & 22.22 & 28.57 & 16.07 & 21.43 & 11.11 & 20 & 8.47 & 16.67 \\
\hline Nasua narica & 25 & 27.78 & 13.04 & 18.75 & - & - & - & - & - & - & - & - & - & - \\
\hline Odocoileus virginianus & 5 & 5.56 & 4.35 & 6.25 & - & - & - & - & 5.36 & 7.14 & - & - & - & - \\
\hline Peromyscus maniculatus & - & - & - & - & - & - & - & - & 1.79 & 2.38 & - & - & 0.56 & 1.11 \\
\hline Peromyscus melanotis & - & - & - & - & - & - & - & - & 1.79 & 2.38 & - & - & - & - \\
\hline Peromyscus aztecus & - & - & - & - & - & - & - & - & 3.57 & 4.76 & - & - & 0.56 & 1.11 \\
\hline Peromyscus melanophrys & - & - & - & - & - & - & - & - & 3.57 & 4.76 & 2.78 & 5 & 0.56 & 1.11 \\
\hline Peromyscus sp. & - & - & - & - & - & - & 7.41 & 9.52 & - & - & - & - & 1.69 & 3.33 \\
\hline Procyon lotor & 1.67 & 1.85 & 4.35 & 6.25 & - & - & - & - & 5.36 & 7.14 & 2.78 & 5 & - & - \\
\hline Sciurus aureogaster & - & - & - & - & 13.33 & 12.5 & - & - & 1.79 & 2.38 & - & - & 0.56 & 1.11 \\
\hline Sylvilagus cunicularius & 6.67 & 7.41 & - & - & 6.67 & 6.25 & 3.7 & 4.76 & 1.79 & 2.38 & - & - & 1.13 & 2.22 \\
\hline Sylvilagus floridanus & 6.67 & 7.41 & 13.04 & 18.75 & - & - & 3.7 & 4.76 & 8.93 & 11.9 & 2.78 & 5 & 1.69 & 3.33 \\
\hline Sylvilagus spp. & 3.33 & 3.7 & - & - & 6.67 & 6.25 & 3.7 & 4.76 & 12.5 & 16.67 & - & - & 1.13 & 2.22 \\
\hline Spermophilus variegatus & - & - & - & - & - & - & - & - & 1.79 & 2.38 & - & - & 1.13 & 2.22 \\
\hline Reitrodonthomys sp. & - & - & - & - & - & - & - & - & 1.79 & 2.38 & - & - & - & - \\
\hline Unidentified mammal & 5 & 5.56 & - & - & - & - & - & - & 1.79 & 2.38 & - & - & - & - \\
\hline \multicolumn{15}{|l|}{ Reptiles } \\
\hline Ctenosaura pectinata & 1.67 & 1.85 & 4.35 & 6.25 & - & - & - & - & - & - & - & - & 0.56 & 1.11 \\
\hline Sceloporus sp. & - & - & - & - & - & - & - & - & - & - & - & - & 0.56 & 1.11 \\
\hline \multicolumn{15}{|l|}{ Arthropods } \\
\hline Coleoptera & - & - & - & - & - & - & - & - & 3.57 & 4.76 & 13.89 & 25 & 5.65 & 11.11 \\
\hline Crustacea & - & - & - & - & - & - & - & - & - & - & - & - & 0.56 & 1.11 \\
\hline Formicidae & - & - & - & - & - & - & 3.7 & 4.76 & 1.79 & 2.38 & 11.11 & 20 & 3.39 & 6.67 \\
\hline Hemiptera & - & - & - & - & - & - & - & - & 1.79 & 2.38 & - & - & - & - \\
\hline Orthoptera & - & - & - & - & 13.33 & 12.5 & 18.52 & 23.81 & 3.57 & 4.76 & 36.11 & 65 & 24.86 & 48.89 \\
\hline \multicolumn{15}{|l|}{ Plants } \\
\hline Byrsonima crassifolia & - & - & - & - & - & - & 3.7 & 4.76 & 1.79 & 2.38 & 2.78 & 5 & 1.13 & 2.22 \\
\hline Capsicum sp. & - & - & - & - & - & - & - & - & - & - & 2.78 & 5 & - & - \\
\hline Crescienta sp. & - & - & - & - & - & - & - & - & - & - & - & - & 5.08 & 10 \\
\hline Ficus sp. & - & - & - & - & - & - & 3.7 & 4.76 & - & - & 2.78 & 5 & 5.08 & 10 \\
\hline Lysiloma sp. & - & - & - & - & - & - & - & - & - & - & - & - & 1.13 & 2.22 \\
\hline Myrmeleon sp. & - & - & - & - & 6.67 & 6.25 & - & - & - & - & - & - & - & - \\
\hline Physalis sp. & - & - & - & - & - & - & 3.7 & 4.76 & - & - & - & - & 0.56 & 1.11 \\
\hline
\end{tabular}


Table 1 Diet of carnivore assemblage analysed through percentage of occurrence and frequency of occurrence, central Mexico (Continued)

\begin{tabular}{|c|c|c|c|c|c|c|c|c|c|c|c|c|c|c|}
\hline Psidium sp. & - & - & - & - & - & - & 3.7 & 4.76 & 1.79 & 3.7 & 11.11 & 20 & 23.73 & 46.67 \\
\hline Zea mays & - & - & - & - & - & - & - & - & - & - & - & - & 3.39 & 6.67 \\
\hline Unidentified plant 1 (seeds) & - & - & - & - & - & - & - & - & - & - & - & - & 1.69 & 3.33 \\
\hline Unidentified plant 2 (shells) & - & - & - & - & - & - & - & - & - & - & - & - & 1.13 & 2.22 \\
\hline \multicolumn{15}{|l|}{ Birds } \\
\hline Buteogallus antharacincus & - & - & - & - & - & - & - & - & 1.79 & 2.38 & - & - & - & - \\
\hline Seiurus sp. & - & - & - & - & - & - & 3.7 & 4.76 & - & - & - & - & - & - \\
\hline Strigidae & - & - & - & - & - & - & - & - & 1.79 & 2.38 & - & - & - & - \\
\hline Unidentified bird & - & - & 4.35 & 6.25 & - & - & - & - & 7.14 & 9.52 & - & - & 3.95 & 7.78 \\
\hline
\end{tabular}

n, scats number.

two guilds: 1) carnivore mesopredators (P. yagouaroundi, L. wiedii and L. pardalis), associated with the consumption of small mammals and birds, and 2) omnivore mesopredators ( $N$. narica and $U$. cinereoargenteus), associated with the consumption of arthropods and plants (fruits, Table 1 and Figure 2).

The dietary niche breadth calculated in this assemblage describes top predators ( $P$. concolor and $P$. onca) as a specialist group and carnivore mesopredators $(L$. wiedii, L. pardalis and P. yagouaroundi) as a generalist group. Finally, omnivore mesopredators ( $N$. narica and $U$. cinereoargenteus) had an intermediate niche breadth between both guilds. Specifically, P. concolor showed the most specialist foraging strategies and $L$. wiedii the most generalist (Table 2).

The mean dietary overlap was 0.54 , indicating an intermediate overlap in the assemblage. Comparison with null models indicated that the observed overlap was significantly greater than the mean simulated overlap $(0.37$, $p=0.002$ ), which means that it was not random. The highest overlap (0.86 to 0.99 ) occurred within generated guilds. In contrast, the lowest overlap was among guilds, particularly when top predators and omnivore mesopredators were compared (0.05 to 0.09 ), which is consistent with the correspondence analysis results (Table 2).

\section{Discussion}

\section{Trophic structure of carnivore assemblage}

Species in a community tend to organise according to body size, which leads them to consume prey with specific characteristics. Therefore, body size differences of predators may influence their ability to hunt large prey, favouring top predators, and restricts the mesopredators to small prey (Konecny 1989; Hayward et al. 2006; Bianchi

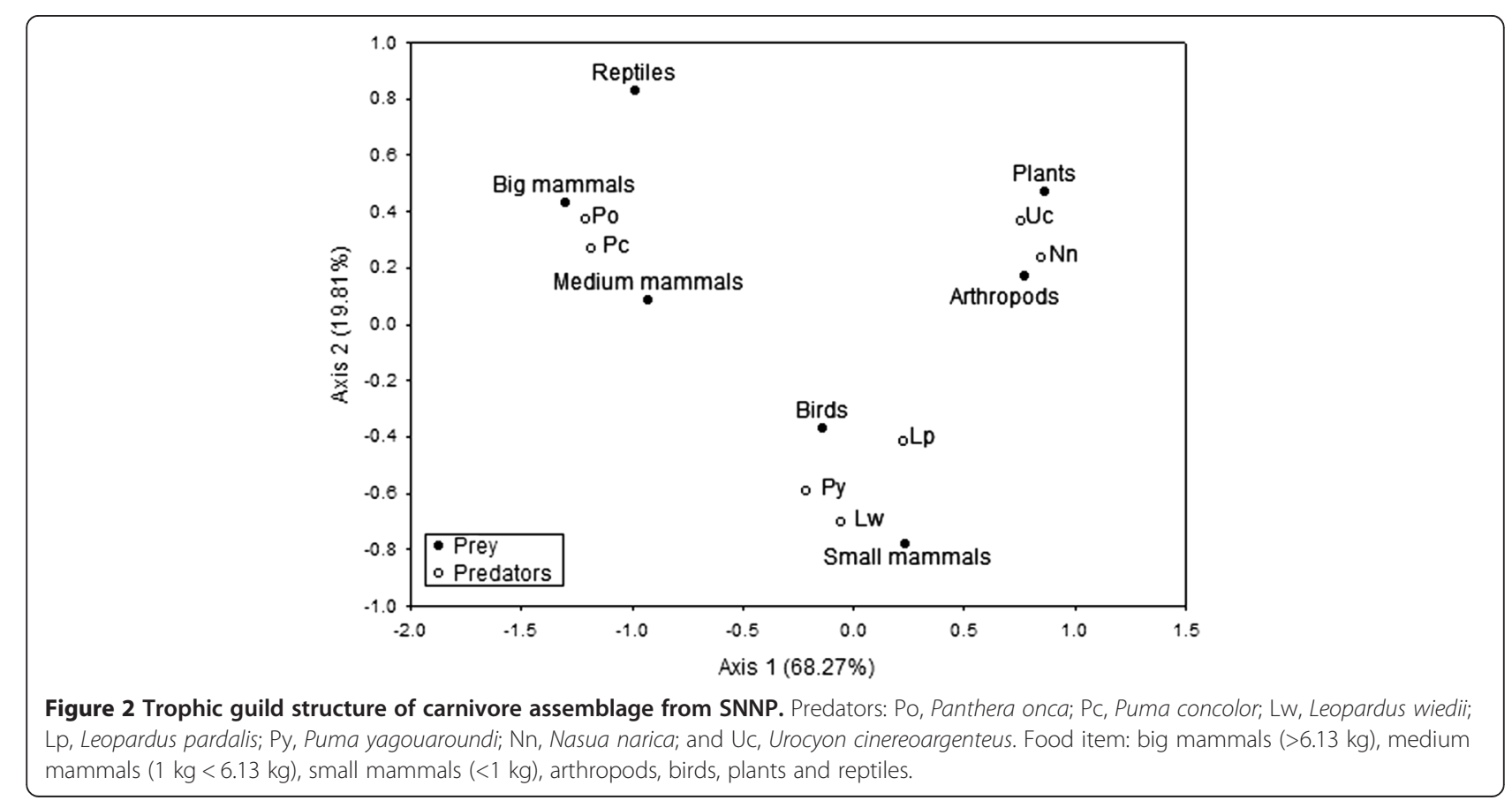


Table 2 Dietary breadth and overlap niche in the diet of a carnivore assemblage in central Mexico

\begin{tabular}{|c|c|c|c|c|c|c|c|}
\hline Overlap & $\begin{array}{l}\text { Puma } \\
\text { concolor }\end{array}$ & $\begin{array}{l}\text { Panthera } \\
\text { onca }\end{array}$ & $\begin{array}{l}\text { Leopardus } \\
\text { wiedii }\end{array}$ & $\begin{array}{l}\text { Leopardus } \\
\text { pardalis }\end{array}$ & $\begin{array}{l}\text { Puma } \\
\text { yagouaroundi }\end{array}$ & $\begin{array}{l}\text { Nasua } \\
\text { narica }\end{array}$ & $\begin{array}{l}\text { Urocyon } \\
\text { cinereoargenteus }\end{array}$ \\
\hline P. concolor & 1 & 0.99 & 0.56 & 0.45 & 0.62 & 0.05 & 0.09 \\
\hline P. onca & & 1 & 0.53 & 0.43 & 0.61 & 0.04 & 0.09 \\
\hline L. wiedii & & & 1 & 0.94 & 0.96 & 0.47 & 0.42 \\
\hline L. pardalis & & & & 1 & 0.92 & 0.67 & 0.69 \\
\hline P. yagoaroundi & & & & & 1 & 0.39 & 0.41 \\
\hline N. narica & & & & & & 1 & 0.86 \\
\hline U. cinereoargenteus & & & & & & & 1 \\
\hline Breadth & 0.1 & 0.24 & 0.86 & 0.71 & 0.54 & 0.42 & 0.42 \\
\hline
\end{tabular}

et al. 2011; Silva-Pereira et al. 2011). Our results suggest that the organisation of species in this assemblage should be explained by body size, because this parameter separates top predators from mesopredators, favours the differential use of feeding resources and potentially reduces competition among guilds (Davies et al. 2007). Top predators (P. onca and P. concolor) were associated with the consumption of medium and large mammals and were similar to reports from other sites of sympatry of these species (Núñez et al. 2000; Scognamillo et al. 2003; Harmsen et al. 2009).

The similarity in body size between species increases the likelihood to hunt the same prey, but our study shows that the coexistence of mesopredators can also be explained by ecological foraging segregation. This is supported by the fact that opportunism and plasticity in feeding of mesopredators reduces convergence in the use of similar resources (Fedriani et al. 1999; Guerrero et al. 2002; Carvalho and Gomes 2004). The diet of carnivore mesopredators was no different to other records where small prey were consumed (Guerrero et al. 2002; Wang 2002; Abreu et al. 2008; Bianchi et al. 2011). Moreover, omnivore mesopredators have been characterised by the consumption of fruits and arthropods (Valenzuela 1998; Fedriani et al. 1999; Guerrero et al. 2002).

\section{Dietary breadth and overlap}

Niche breadth has been used as a parameter to reference the dominance of species, so that the dominant species chooses times or sites in which their main prey can be found. Instead, subordinate species are confined to times or spaces in which the dominant species is absent, becoming a generalist forager in both niche dimensions. Resource segregation can also be modelled by evolutionary forces when the dominant species are sympatric leading to a reduction in their niche (Caro and Stoner 2003; Hayward and Slotow 2009). The niche breadth patterns in the assemblage we studied support the coexistence of predators and the community structure, placing top predators as specialist, carnivore mesopredators as generalist and omnivore mesopredators with intermediate breadth.

The high dietary overlap between species with similar morphology and diet are reported in most of the studies where these species are sympatric (Núñez et al. 2000; Guerrero et al. 2002; Scognamillo et al. 2003; SilvaPereira et al. 2011; Gómez-Ortiz and Monroy-Vilchis 2013), because throughout their distribution, there is a similar prey base. In SNNP, competition between top predators should be taken with caution due to the low abundance of jaguar in this site and different activity patterns (Monroy-Vilchis et al. 2009b; Soria-Díaz et al. 2010); also, there are insufficient data to corroborate competition, so it is necessary to carefully evaluate resource availability and the requirements of each predator. The absence or low density of a top predator lets competitive release of subordinate predators and the expansion of their niches by changing predation patterns (Moreno et al. 2006). In this case, such release is not observed, possibly due to the low diversity of large prey (Odocoileus virginianus) and the existence of a high diversity of small and medium prey (Monroy-Vilchis et al. 2011).

In carnivore mesopredators, there is a high overlap that can be supported by an adequate availability of small rodents. In SNNP, rodents are represented by a high species richness (Muridae: 13 spp., Heteromidae: 1 sp., Monroy-Vilchis et al. 2011), which may favour the coexistence, as reported in Brazil (Silva-Pereira et al. 2011). Omnivore mesopredators also have a high overlap; however, $N$. narica consumed more orthopterans than fruits (Psidium sp.) in contrast to $U$. cinereoargenteus.

The occasional consumption of birds, reptiles and some domestic species has been reported in the diet of mesopredators (Emmons 1987; Wang 2002; Abreu et al. 2008). Moreover, our data suggest an occasional consumption on domestic goat (Capra hircus) and corn (Zea mays). In SNNR, human-wildlife conflicts have been recorded and individuals of $P$. concolor have been 
killed (Zarco-González et al. 2012), as well as the unjustified hunting of mesopredators ( $P$. yagouaroundi, $N$. narica and $U$. cinereoargenteus) due to their supposed relation with predation on poultry and corn crops (Romero-Balderas et al. 2006).

Additional data on resource availability could provide more accurate answers regarding competition as a structuring mechanism in the assemblage we studied. In a previous study of prey selection in SNNP, we found that $P$. concolor selects its prey (Gómez-Ortiz and MonroyVilchis 2013). It is therefore necessary to focus future studies on assessing the availability of resources and identifying the role of key species, since the management and conservation of biodiversity must be maintained for the persistence of carnivores and those species that have a key role, such as D. novemcinctus in this study.

\section{Conclusions}

The analysis allowed us to identify the main feeding strategies of a carnivore assemblage in central Mexico. The coexistence in this carnivore assemblage appears to be related to body size, morphology and prey segregation, because such characteristics suggest the presence of three guilds. We observed high dietary overlap within guilds and resource partitioning between guilds.

\section{Competing interests}

The authors declare that they have no competing interests.

\section{Authors' contributions}

$\mathrm{OM}-\mathrm{V}$ and $\mathrm{YG}-\mathrm{O}$ conceived and designed the surveys and obtained the data. YG-O, OM-V and GDM-M analysed and interpreted the data. YG-O, OM-V and GDM-M wrote the manuscript. All authors read and approved the final manuscript.

\section{Acknowledgements}

We thank the Mexicans and the 'Consejo Nacional de Ciencia y Tecnología' for the economic support for this study through project funding (105254) and scholarship (255868). We also thank 'Programa de Mejoramiento del Profesorado' for funding the project 103.5/10/0942. We thank all students and rangers of Sierra Nanchititla Biological Station (Universidad Autónoma del Estado de México) for their support in the field and the 'Comisión Estatal de Parques Naturales y de la Fauna' for providing us with carnivore scats for identification by bile acids. We express thanks to A. Salame-Méndez and H. Domínguez-Vega for their support in this study.

\footnotetext{
Author details

${ }^{1}$ Estación Biológica Sierra Nanchititla, Facultad de Ciencias, Universidad Autónoma del Estado de México, Instituto Literario 100, Colonia Centro, Toluca, CP 50000, México. ${ }^{2}$ Departamento de Producción Agrícola y Animal, Universidad Autónoma Metropolitana, Xochimilco, Calzada del Hueso 1100, Distrito Federal 04960, México.
}

Received: 1 July 2014 Accepted: 30 December 2014 Published online: 16 January 2015

\section{References}

Abreu KC, Moro-Rios F, Silva-Pereira JE, Miranda JMD, Jablonski EFJ, Passos FC (2008) Feeding habits of ocelot (Leopardus pardalis) in Southern Brazil. Mamm Biol 73:407-411

Bianchi RC, Rosa AF, Gatti A, Mendez SL (2011) Diet of margay, Leopardus wiedii, and jaguarondi, Puma yagouarondi, (Carnivora: Felidae) in Atlantic Rainforest, Brazil. Zoologia 28:127-132
Caro TM, Stoner CJ (2003) The potential for interspecific competition among African carnivores. Biol Conserv 110:67-75

Carvalho JC, Gomes P (2004) Feeding resources partitioning among four sympatric carnivores in the Peneda-Gerés National Park (Portugal). J Zool 263:275-283

Cazón AV, Sühring S (1999) A technique for extraction and thin layer chromatography visualization of fecal acids applied to Neotropical felid cats. Rev Biol Trop 47:245-249

Davies TJ, Meiri S, Barraclough TG, Gittleman JL (2007) Species co-existence and character divergence across carnivores. Ecol Lett 10:146-152

Emmons LH (1987) Comparative feeding ecology of felids in a tropical rainforest. Behav Ecol Sociobiol 20:271-283

Ernest H, Penedo M, May B, Sywanen S, Boyce W (2000) Molecular tracking of mountain lions in the Yosemite Valley region in California: genetic analysis using microsatellites and fecal DNA. Molecular Ecology 9:433-441

Fedriani JM, Palomares F, Delibes M (1999) Niche relations among three sympatric Mediterranean carnivores. Oecologia 121:138-148

Fernández GJ, Corley JC, Capurro AF (1997) Identification of cougar and jaguar feces through bile acid chromatography. J Wildl Manage 61:506-510

Gómez-Ortiz Y, Monroy-Vilchis O (2013) Feeding ecology of puma Puma concolor in Mexican montane forests with comments about jaguar Panthera onca. Wildl Biol 19:179-187

Gómez-Ortiz Y, Monroy-Vilchis O, Fajardo V, Mendoza GD, Urios V (2011) Is food quality important for carnivores? The case of Puma concolor. Anim Biol 61:277-288

Gotelli NJ, Entsminger GL (2005) EcoSim: null models software for ecology, vol 7. Acquired Intelligence Inc. \& Kesey-Bear, Burlington

Guerrero S, Badii MH, Zalapa SS, Flores AE (2002) Dieta y nicho de alimentación del coyote, zorra gris, mapache y jaguarundi en un bosque tropical caducifolio de la costa sur del estado de Jalisco, México. Acta Zool Mex 86:119-137

Harmsen BJ, Foster RJ, Silver SC, Ostro LET, Doncaster P (2009) Spatial and temporal interactions of sympatric jaguars (Panthera onca) and (Puma concolor) in a Neotropical forest. J Mammal 90:612-620

Hayward MW, Slotow R (2009) Temporal partitioning of activity in large African carnivores: tests of multiple hypotheses. S Afr J Wildl Res 39:109-125

Hayward MW, Henschel P, O'Brien J, Hofmeyer M, Balme G, Kerley GIH (2006) Prey preferences of the leopard (Panthera pardus). J Zool 270:298-313

Jaksic FM (1981) Abuse and misuse of the term "guild" in ecological studies. Oikos 37:397-400

Jaksic FM, Feinsinger P, Jiménez JE (1996) Ecological redundancy and long-term dynamics of vertebrates predators in semiarid Chile. Conserv Biol 10:252-262

Konecny MJ (1989) Movement patterns and food habitats of four sympatric carnivore species in Belize, Central America. In: Redford KH, Eisenberg JF (eds) Advances in Neotropical mammalogy. Sadhill Crane Press, Florida, pp 243-264

MacArthur RH, Levins R (1967) The limiting similarity, convergence, and divergence of coexisting species. Am Natur 101:377-385

Major M, Johnson MK, Davis WS, Kellog TF (1980) Identifying scats by recovery of bile acids. J Wildl Manage 44:290-293

Monroy-Vilchis O, Rubio-Rodríguez R (2003) Guía de identificación de mamíferos terrestres del Estado de México, a través del pelo de guardia. Universidad Autónoma del Estado de México, México

Monroy-Vilchis O, Zarco-González M, Rodríguez-Soto C, Suárez P, Urios V (2008) Uso tradicional de vertebrados silvestres en la Sierra Nanchititla, México. Interciencia 33:308-313

Monroy-Vilchis O, Gómez Y, Janczur M, Urios V (2009a) Food niche of Puma concolor in Central Mexico. Wildl Biol 15:97-105

Monroy-Vilchis O, Rodríguez-Soto C, Zarco-González M, Urios V (2009b) Cougar and jaguar habitat use and activity patterns in central Mexico. Anim Biol 59:145-157

Monroy-Vilchis O, Zarco-González MM, Ramírez-Pulido J, Aguilera-Reyes U (2011) Diversidad de mamíferos de la Reserva Natural Sierra Nanchititla, México. Rev Mex Biodiv 82:237-248

Monroy-Vilchis O, Gómez-Ortiz Y, Urios V (2013) Expulsion rate of Puma concolor (Carnivora: Felidae) in captivity. Mamm Stud 38:299-302

Moreno RS, Kays RW, Samudio R (2006) Competitive release in diets of ocelot (Leopardus pardalis) and puma (Puma concolor) after jaguar (Panthera onca) decline. J Mammal 87:808-816

Núñez R, Miller B, Lindzey F (2000) Food habits of jaguars and pumas in Jalisco, Mexico. J Zool 252:373-379 
Pianka ER (1973) The structure of lizard communities. Annu Rev Ecol Syst 4:53-74

Ray JC, Sunquist ME (2001) Trophic relations in a community of African rainforest carnivores. Oecologia 127:395-408

Ritchie EG, Johnson CN (2009) Predator interactions, mesopredator release and biodiversity conservation. Ecol Lett 12:982-998

Romero-Balderas KG, Naranjo EJ, Morales HH, Nigh RB (2006) Daños ocasionados por vertebrados silvestres al cultivo de maíz en la selva lacandona, Chiapas, México. Interciencia 31:276-283

Root RB (1967) The niche exploitation pattern of the blue-gray gnatcatcher. Ecol Monogr 37:317-350

Salame-Méndez A, Andrade-Herrera M, Zamora-Torres L, Serrano H, SotoMendoza S, Castro-Campillo A, Ramírez-Pulido J, Haro-Castellanos J (2012) Método optimizado para evaluar ácidos biliares de muestras fecales secas o preservadas en etanol como herramienta para identificar carnívoros silvestres. Acta Zool Mex 28:305-320

Schoener TW (1974) Resource partitioning in ecological communities. Science 185:27-39

Schoener TW (1982) The controversy over interspecific competition. Am Sci 70:27-39

Scognamillo D, Maxit I, Sunquist M, Polisar J (2003) Coexistence of jaguar (Panthera onca) and puma (Puma concolor) in a mosaic landscape in the Venezuelan Ilanos. J Zool 259:269-279

Silva-Pereira JE, Moro-Rios RF, Bilski DR, Passos FC (2011) Diets of three sympatric Neotropical small cats: food niche overlap and interspecies differences in prey consumption. Mamm Biol 76:308-312

Simberloff D, Dayan T (1991) The guild concept and the structure of ecological communities. Ann Rev Ecolog Syst 22:115-143

Soria-Díaz L, Monroy-Vilchis O, Rodríguez-Soto C, Zarco-González MM, Urios V (2010) Variation of abundance and density of Puma concolor in zones of high and low concentration of camera traps in central Mexico. Anim Biol 60:361-371

Taber A, Novaro A, Neris N, Colman F (1997) The food habits of sympatric jaguar and puma in the Paraguayan Chaco. Biotropica 29:204-213

Valenzuela D (1998) Natural history of the white-nosed coati, Nasua narica, in a tropical dry forest of western México. RMM 3:26-44

Wang E (2002) Diets of ocelots (Leopardus pardalis), margays (L. wiedii), and oncillas (L. tigrinus) in the Atlantic rainforest in southeast Brazil. Stud Neotrop Fauna E 37:207-212

Winemiller KO, Pianka ER (1990) Organization in natural assemblages of desert lizards and tropical fishes. Ecol Monogr 60:27-55

Zapata SC, Travaini A, Ferreras P, Delibes M (2007) Analysis of trophic structure of two carnivore assemblages by means of guild identification. Eur J Wild Res 53:276-286

Zarco-González MM, Monroy-Vilchis O, Rodríguez-Soto C, Urios V (2012) Spatial factors and management associated with livestock predations by Puma concolor in Central Mexico. Hum Ecol 40:631-638

\section{Submit your manuscript to a SpringerOpen ${ }^{\circ}$ journal and benefit from:}

- Convenient online submission

- Rigorous peer review

- Immediate publication on acceptance

- Open access: articles freely available online

- High visibility within the field

- Retaining the copyright to your article

Submit your next manuscript at $>$ springeropen.com 